\title{
Recent Excavations at Slussen in Stockholm
}

\author{
Kenneth Svensson, Arkeologikonsult
}

The Slussen area of central Stockholm is currently undergoing unprecedented redevelopment. Archaeological excavations in advance of this work have been underway since 2013. The initial investigations were conducted in three phases, each of limited duration, but from summer 2016 onwards, excavations have been carried out continuously, all year round. We esti-mate that the fieldwork will be complete by 2023 , making the project the most comprehensive archaeological investigation ever carried out in Stock-holm. By this date we will have excavated and recorded a total area of just over two hectares, almost three times the size of the excavations at Helge-andsholmen in 1978-1980, in advance of the construction of the Swedish Parliament (Dahlbäck I982).

When the excavations began in autumn 2013 , very little was known of the early history of the Slussen area of the island of Södermalm. Although conventional academic wisdom acknowledged some form of early settlement at Åsön (the medieval name for Södermalm) immediately across the water from Stadsholmen (Gamla Stan), its nature was deemed scattered and intermittent. This notion derives mainly from late medieval written sources, which state, for example, that only kitchen gardens and makeshift buildings were permitted at Åsön. Military defence considerations would have given rise to sporadic settlement too, as would the ancient tradition by which the townsfolk pastured their animals at Åsön during the summer half of the year (Hasselmo I98 I:20I, 2 I3; Söderlund 2004: I I I).

Our excavations have already yielded vast amounts of new information. The area contains archaeological remains dating from between the late Viking Age and the mid-nineteenth century, and in fact traces of habitation continue as far as the I930s. Findings show not only that urbanisation in Stockholm was a much more complex process than was previously thought, but also that the population of the Slussen area was far more so- 


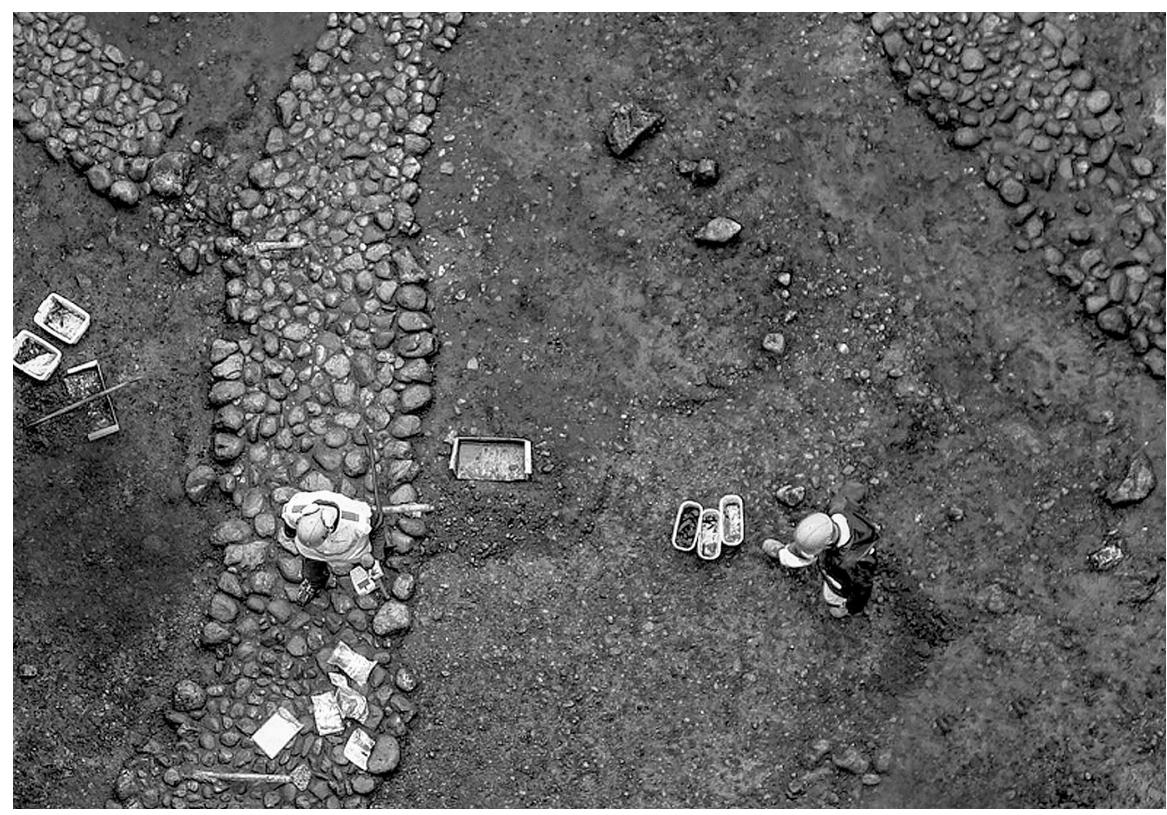

Figure I. These narrow, winding stone-paved streets date to circa I320. They were found at Södermalmstorg and are probably the oldest stone-paved streets found in Stockholm.

cially diverse and affluent than medieval sources suggest (Carlsson \& Svensson 2019; Svensson 2020). A chronological summary of results to date is presented here.

Initially in the late Viking period we see that the area was a stopover on boat journeys to and from Lake Mälaren, with travellers leaving evidence in the form of cooking pits where food was prepared.

Activity increased from the I $28 \mathrm{os}$. Remains include a feature most likely to have been a fishpond, which, if so, may relate to a plot of land that King Magnus Birgersson gifted to the Franciscan Order of friars in I 288.

By 1320 at the latest, the area of present-day Södermalmstorg had evolved into a settlement with a clearly suburban nature. Property plots were staked out, and narrow, winding stone-paved streets were established, some no more than a metre wide (Figure I).

Initially, the main occupants of these newly established plots appear to be metalworkers. Finds of metal clippings (mainly bronze), charcoal, scale and slag point to smithing and perhaps founding too. Plots at this time took an irregular form, which suggests the settlement grew organically as increasing numbers of craftworkers moved into the area.

On the shores of the Baltic Sea to the east and Lake Mälaren to the west, dendrochronology has enabled us to date various types of waterfront feature - such as jetties, wharves and revetments - built between the I340s 
and I360s. A noticeable restructuring of the settlement occurred in the mid-fourteenth century, when the plots were redefined, the street network was altered to a more regularised form, and thoroughfares were laid out, as known from the mid-fourteenth-century Town Law of King Magnus Eriksson.

Finds include large quantities of brick, suggesting that many buildings were of half-timbered design. Even at this relatively early date, buildings were provided with tile roofs and often fitted with sandstone-slab floors and coloured-glass windows. In other words, we are dealing with grand secular buildings that reflect considerable wealth. This luxurious standard of living is confirmed by finds of glass drinking vessels and ceramics, including sherds of a unique enamelled glass beaker from Venice and pottery from Persia.

The plots excavated to date appear to have been owned and inhabited by wealthy German merchants, a notion supported by German medieval written records, in which various entries refer to Germans with links to Södermalm (Koppe 1933:I02).

In the late I390s, there was further dramatic change to the Södermalmstorg settlement: it was razed to the ground. This act was probably carried out at the same time as Stockholm's defences were altered to include a new town wall, which featured a gate only I5om from the site of the former settlement. After the settlement was swept away in the fourteenth century, it took until the late fifteenth century before new buildings emerged in the area. This new settlement, despite having regular plots demarcated by stone-paved streets, differed in character from its predecessor. Now the concept of ownership appears to have been diffuse and transient, given the shifting of plot and street boundaries over relatively short periods of time.

We see how plots were put to diverse uses. One plot might be taken up by a single property whose buildings - a dwelling house, cowshed, kitchen and storehouses - were focused around a central courtyard and well. Conversely, a neighbouring plot might feature various storehouses located close together, sometimes packed so tightly as to resemble a shanty town. Storehouses of this kind were usually constructed with reused building materials and chance items, such as the side of an old boat and discarded wooden stakes, the latter being laid beneath floors.

In contrast to the storehouses, the dwelling houses suggest the owners were relatively affluent. Homes were built of brick (probably half-timbered constructions) with tile roofs and floors covered with green- and yellowglazed tiles. Some houses even featured moulded-brick decoration. Windows were glazed with coloured glass, and sometimes plain, high-quality crown glass was used too. One late fifteenth-century innovation was the tile stove, used for heating homes. Evidence of luxury consumption of the 


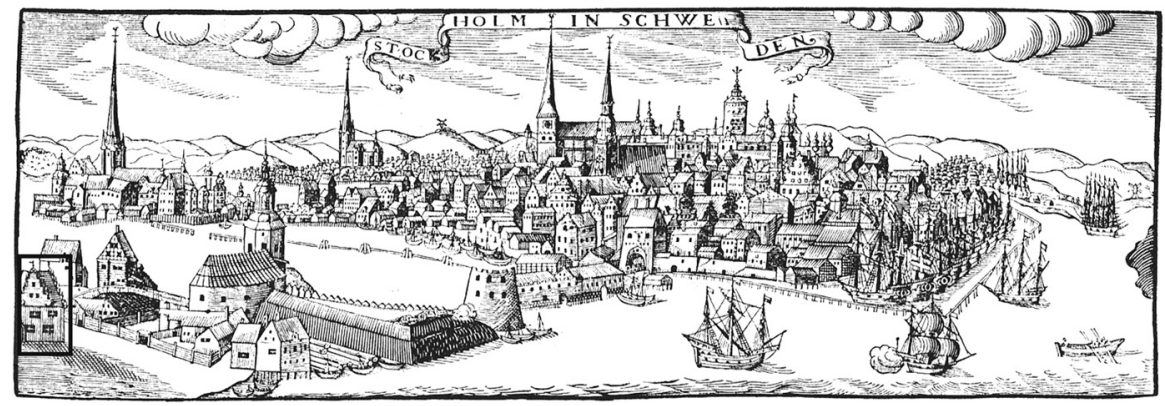

Figure 2. Panorama over Stockholm by Henrik Keyser, I637. The building excavated at Södermalmstorg is marked with a black rectangle in the left corner.

kind seen in the fourteenth century was absent in the first half of the sixteenth century. On the other hand, the find material is abundant, varied and often of good quality.

In circa 1550 the settlement was razed yet again, this time for clearly defensive reasons. King Gustav Vasa now constructed a new moat, a cannon tower and a new town gate. After the settlement was demolished or burnt down, its remains were sealed beneath thick layers of gravel, remodelling the topography of the area outside the south gate. However, by around I600 Gustav Vasa's fortifications were already apparently obsolete, for a new settlement began to grow up alongside the moat. We see how an affluent quarter emerged here before the streets were regularised in the I640s, the decade traditionally seen as the starting point for the influx of moneyed classes to the area.

When excavating Södermalmstorg square in autumn 2013, we uncovered the cellar of a stone house built in around 1600 . The cellar comprised two rooms, one of which was the kitchen. This building is almost certainly pictured on a woodcut of I637 (Figure 2). If so, the Södermalmstorg building featured two aboveground storeys and stepped gables. The ground floor covered an area of at least $360 \mathrm{~m} 2$, making the building one of the largest in Södermalm at this time. The house was demolished when the street layout was regularised in the late I640s, meaning the building had a lifespan of less than fifty years.

During this period we see examples of exclusive window glass in the area. Some finds comprise red or blue glass sherds; other fragments, featuring painted foliage motifs, derive from oriel windows, which in the early modern period were a common feature of affluent burghers' homes. Other sherds include a couple decorated with diamond-engraved foliage and text, a relatively uncommon type of design at this time. The finds also include beautifully decorated tin-glaze earthenware chargers and bowls from Portugal, Italy and Holland. Finds of glass demonstrate that wine was drunk 
from Façon de Venise goblets, and beer was consumed from tall enamelled glass Humpen beakers.

The owners of these luxurious homes appear to have earned some of their wealth from the textile trade. A small area beside a probable trade stall, in use from I625 to I637, yielded textile seals from Germany, England and Holland. This trade may have been conducted by Dutch merchants from Amsterdam, the city where many of the provenanced clay pipes originated. This is unusual: the majority of early seventeenth-century Dutch pipes in Stockholm come from Gouda, whereas Amsterdam pipes are rare.

The next major phase of urban clearance took place when the Södermalm district was regularised in the I640s, the old being swept away to accommodate the new. In this era - when Sweden was a Great Power - the Slussen area became an economic hub. As the military defences were phased out, a growing emphasis was placed on commerce. Slussen became the national centre for the iron trade, with the redundant moat being repurposed for transport. Here bar iron arriving from the Bergslagen region was weighed and transhipped before being exported to Europe. In the late sixteenth century, a new technology for iron production had been introduced to Sweden by workers recruited from Wallonia and Holland to man the Crown's ironworks and weapons workshops. One key figure was the Dutch financier Louis de Geer, who in the I640s bought land on Götgatan in Stockholm, where he built a palace as the centre of his business empire in Sweden.

Louis de Geer's palace, which still stands to this day, is located outside the Slussen redevelopment area. Nevertheless, the excavations provided us with the opportunity to investigate the remains of other major buildings of similar date. These structures, built by rich merchants, sometimes survived to a height of four storeys. Given that these buildings were used until I9I I, finds of seventeenth-century date were rare, and the structures themselves had been altered over time. Yet they still provide a good overview of the urban transformation of the Slussen area (Carlsson 2020).

Across much of the area of excavation are remains that relate to waterfront activities, which in the early modern period were carried out adjacent to the Söderström channel and the docks. For example, in the area of late seventeenth-century docks, on the Baltic side of Slussen, we unearthed the remains of Ryssgarden, a trading centre used by Russian merchants. Excavated features here generally comprised the remains of market stalls and warehouses.

A central factor in the area's transformation from strategic military strongpoint to economic centre is the succession of locks that have been located on the site, the earliest of which was built in the I650s. A prime example of this development is the mid-eighteenth-century Christopher Polhem lock, much of which we found to be extant. 


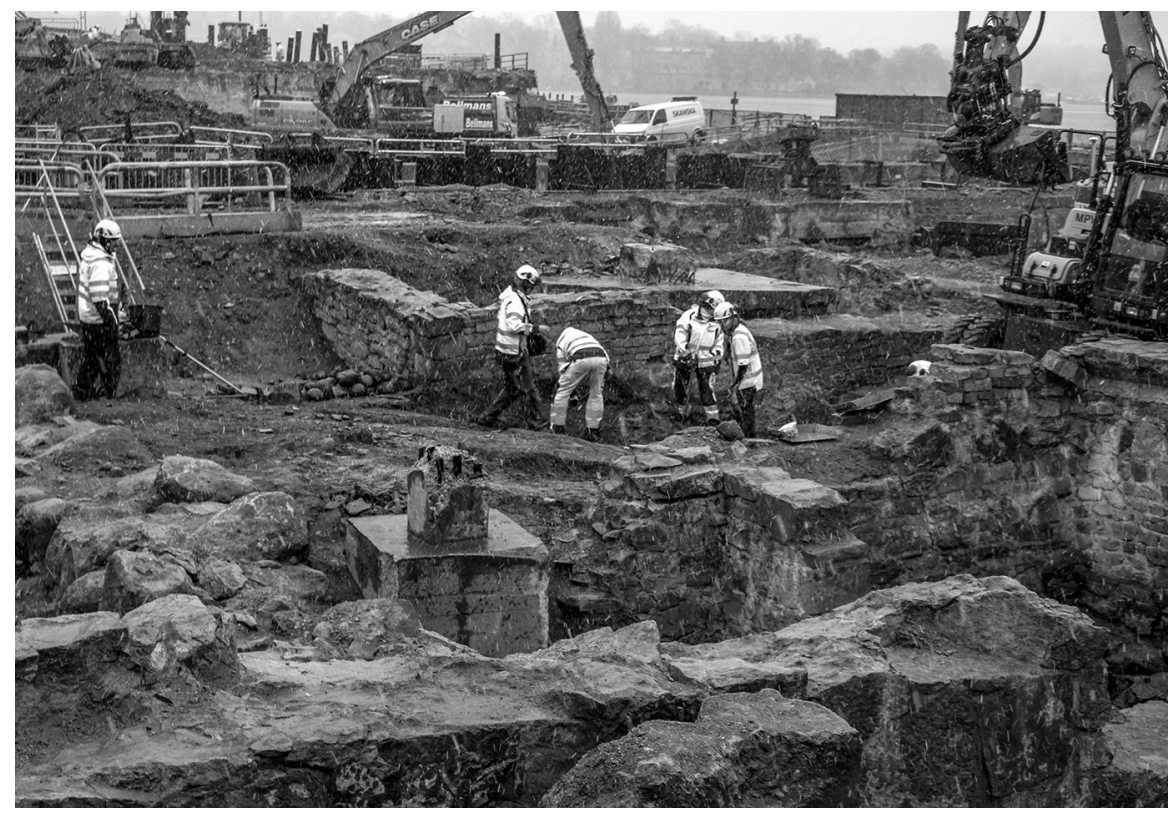

Figure 3. Remains of eighteenth-century stalls that once surrounded Gröna Gången, a central food market.

Excavated eighteenth- and early nineteenth-century remains yielded evidence of the many activities that were attracted to the area at this time, drawn here either by shipping or trade, or by the waterpower of the Söderström channel. Here we excavated the remains of a harbour kitchen building, the hay measurer's office, the city's southern abattoir, and the foundations of various grinderies and breweries. We also investigated the remains of the many stalls that once surrounded Gröna Gången, a central food market (Figure 3).

This chronological summary ends here, but our excavations continue. The results, once processed and analysed, will make a major contribution to urban archaeology in Sweden, and provide clear incentives to future discussions on urban living as a way of life, among other subjects.

English translation: Aiden Allen

\section{References}

Carlsson, M. \& Svensson. K. 20I9. In fundo dicto Suthremalm iam de nouo constructum... Arkeologisk dokumentation av bebyggelsen i den nya medeltida stadsdelen på Södermalm. Lämningar frän vikingatid till I600-talets mitt. Stockholm I03:I, L2015:7789, 
Stockholms stad och kommun, Stockholms län. Slussenprojektet I. Rapporter från Arkeologikonsult 2019:2746. Stockholm: Arkeologikonsult.

Carlsson, M. 2020. Aldrig har storstadens elände trätt mig mer påtagligt och obölit till mötes, än just här: Arkeologi och människor i kvarteret Ormen och Glasbruket Större påSödermalm. Lämningar frän tidigt I600-tal till I900-talet. Stockholm I03:I, Stockholms stad och kommun, Stockholms län. Slussenprojektet 2. Rapporter från Arkeologikonsult 2020:3039. Stockholm: Arkeologikonsult.

Dahlbäck, G. (ed.). I982. Helgeandsholmen: I0oo år i Stockholms ström. Monografier utgivna av Stockholms kommun 48. Stockholm: Liber förlag.

Hasselmo, M. I98I. Stockholm. Medeltidsstaden I7. Stockholm: Riksantikvarieämbetet och Statens Historiska Museer.

Koppe, W. I933. Lübeck-Stockholmer Handelsgeschichte im I4. Jahrhundert. Neumünster: Wachholtz.

Svensson, K. (ed.). 2020. Upptäckten av en medeltida förstad på Södermalm i Stockholm: En rapport frän ett vetenskapligt seminarium kring de fynd som gjorts inom Slussenprojektet. Skrifter från Arkeologikonsult nr 7. Stockholm: Arkeologikonsult.

Söderlund, K. 2004. Staden. Vetenskapligt program för den arkeologiska verksambeten vid Stockholms stadsmuseum. Rapport 2004:5. Stockholm: Stockholms stadsmuseum. 